\title{
Investigasi Pengaruh Skenario Modifikasi Urbanisasi pada Perubahan Hujan di Kota Makassar
}

\author{
Fitria Puspita Sari ${ }^{1}$, Satriawan Nadhrotal Atsidiqi ${ }^{2}$ \\ 1 Program Studi D-IV Meteorologi, Sekolah Tinggi Meteorologi Klimatologi dan Geofisika, \\ Jl. Perhubungan I No,5, Pondok Betung, Tangerang Selatan, Banten \\ 2 Stasiun Meteorologi Sangia Ni Bandera, Jl. Protolo No.1 Pomala, Kolaka, Sulawesi Utara \\ Email : fitria.sari@stmkg.ac.id
}

\begin{abstract}
Urbanization affects the atmosphere through the urban heat island (UHI) process, resulting in the change of rain patterns over urban areas. Makassar as the one of big cities in Indonesia is assumed to be suffering from this effect, thus an investigation related to the issue needs to be done. This study contains a simulation of urbanization scenarios using a three-dimensional non-hydrostatic Weather Research and Forecasting (WRF) Model during the transition monsoon period: SeptemberOctober-November (SON) 2014-2018. The study covers 5 selected heavy-rain-event during the SON period: 24 September 2016, 9 October 2016, 24 October 2016, 22 November 2016, and 23 September 2017. Result shows that the model is able to simulate some weather parameters with relatively small root-mean-square-error (RMSE) and high correlation on three rain event cases. Afterwards, scenarios of 25\% and 50\% increasing urban area towards Makassar coastal line (as reclamation plan) and existing urban areas have been done. The results show that urbanization increases daily average temperature over urban areas, so does UHI maximum reach number of $1.5^{\circ} \mathrm{C}$ for both scenarios on 24 September 2016 rain event. Also, it increases rain accumulation up to 50\% over reclamation areas and relativeky decreases rainfall over existing urban areas.
\end{abstract}

Keywords: urbanization, UHI, rainfall accumulation, modification scenario, WRF Model

\begin{abstract}
Abstrak: Peningkatan jumlah penduduk dan kegiatan urbanisasi dapat mengubah interaksi atmosfer melalui penambahan pelepasan panas yang menyebabkan terjadinya efek urban heat islands (UHI) serta perubahan hujan di wilayah perkotaan. Sebagai salah satu kota metropolitan di Indonesia, Makassar dimungkinkan terdampak oleh efek UHI tersebut. Sehingga penelitian ini dilakukan untuk mengetahui dampak urbanisasi terhadap perubahan akumulasi dan/atau pola hujan di wilayah Makassar sesuai skenario jumlah penduduk tahun 2045. Investigasi dilakukan dengan memanfaatkan model nonhidrostatik tiga dimensi Weather Research and Forecasting (WRF) pada musim transisi SeptemberOktober-November (SON) 2014-2018. Kejadian hujan lebat terpilih sebanyak 5 hari yakni tanggal 24 September 2016, 9 Oktober 2016, 24 Oktober 2016, 22 November 2016, dan 23 September 2017. Verifikasi model dilakukan dengan menggunakan metode statistik. Hasilnya, model mampu digunakan untuk mensimulasikan tiga dari lima kejadian hujan lebat dengan nilai RMSE relatif rendah dan korelasi tinggi. Selanjutnya, skenario modifikasi dilakukan dengan menambahkan wilayah urban sebesar $25 \%$ dan 50\% untuk masing-masing area di bagian pantai (sesuai rencana reklamasi) dan taman kota. Dari hasil simulasi hujan lebat tanggal 24 September 2016 diketahui bahwa urbanisasi meningkatkan rataan suhu harian wilayah perkotaan yang menyebabakan UHI maksimum meningkat antara $0.1^{\circ}$ hingga $1.5^{\circ} \mathrm{C}$ pada dua skenario modifikasi. Selain itu skenario modifikasi urbanisasi menyebabkan peningkatan hujan sebesar 50\% di area reklamasi dan cenderung normal bahkan mengalami penurunan di wilayah taman kota sekitar Universitas Hasanuddin.
\end{abstract}

Kata kunci: urbanisasi, UHI, akumulasi hujan, skenario modifikasi, Model WRF 


\section{PENDAHULUAN}

Berdasarkan laporan PBB, Kota Makassar merupakan salah satu kota di Indonesia yang menjadi tujuan aktivitas urbanisasi (UN-HABITAT, 2013). Sehingga pertambahan penduduk serta perubahan tata guna lahan adalah hal yang pasti pada wilayah tersebut untuk beberapa tahun kedepan. Badan Pusat Statsitik (BPS, 2018) mencatat penduduk di Kota Makassar mengalami peningkatan 9,81\% dari tahun 2010, dengan kepadatan penduduk 8.471 jiwa setiap $1 \mathrm{~km}^{2}$. Padahal urbanisasi dapat memengaruhi kondisi atmosfer salah satunya adalah terbentuknya fenomena Urban Heat Island (UHI) dimana wilayah perkotaan lebih hangat dibandingkan wilayah pedesaan (Delarizka, A. et al., 2016).

Selain UHI, urbanisasi berdampak pada sebaran dan pola hujan di wilayah kota. Han, J. Y., et al., (2014) pada penelitiannya mengemukakan bahwa adanya perluasan wilayah kota menyebabkan adanya efek bifurcate, dimana awan konvektif bercabang menjadi dua ketika memasuki wilayah kota sehingga menyebabkan adanya peningkatan dan penurunan curah hujan di wilayah kota. Yu dan Liu (2015) yang menyimulasikan kejadian hujan lebat di Kota Beijing dengan model Weather Research and Forecasting (WRF) menghasilkan bahwa urbanisasi meningkatkan akumulasi hujan serta distribusi hujan yang terkonsentrasi di wilayah perkotaan. Niyogi, D., et al., (2017) dalam penelitiannya di Amerika Serikat juga menemukan bahwa urbanisasi menyebabkan peningkatan dan penurunan jumlah dan frekuensi hujan akibat adanya pengaruh sebaran antropogenik di wilayah yang berbeda.

Penelitian terkait perubahan sebaran pola hujan juga pernah dilakukan di Makassar. Paida (2011) yang mengolah data hujan selama 28 tahun menemukakan bahwa selama tahun 19842011 tidak terdapat perubahan curah hujan yang signifikan di Makassar. Ihsan, H., et al., (2019) dengan metode Model Rantai Markov menemukan bahwa sebesar 55\% daerah Paotere berpeluang hujan. Namun sayangnya penelitian yang mencoba mengaitkan adanya pengaruh urbanisasi dengan sebaran curah hujan di Indonesia lebih banyak difokuskan di Jakarta (Prasasti et al., 2015; Syamsudin dan Sopia, 2017). Padahal pada tahun 2045 penduduk Indonesia yang tinggal di wilayah perkotaan diproyeksikan meningkat menjadi $69.1 \%$ dimana daerah Sulawesi akan menjadi basis industri pangan dan gerbang untuk area Kawasan Timur Indonesia (KTI) (BAPPENAS, 2019). Oleh karena itu penelitian ini bermaksud untuk mengetahui apakah perluasan wilayah kota Makassar sebagai calon pusat KTI dapat meningkatkan akumulasi hujan dan berpengaruh terhadap pola sebarannya. Sebagai penelitian pionir, maka fokus penelitian hanya pada analisis paremeter suhu, UHI, dan curah hujan yang dimana pengaruh urbanisasi dikuantifikasi menggunakan skenario modifikasi perluasan wilayah kemudian disimulasikan menggunakan model cuaca non-hidrostatik WRF.

\section{METODE PENELITIAN}

Lokasi yang menjadi fokus penelitian pada wilayah ini adalah kota Makassar yang disimulasikan pada model sesuai penggunaan lahannya (Gambar 1). Untuk titik pengamatan yang digunakan sebagai koordinat area perkotaan dan pedesaan adalah masing-masing Stasiun Kelas II Maritim Paotere-Makassar (119²5'11.28" BT; 506'37.47" LS) dan Stasiun Klimatologi Kelas I Maros (119³4'20.03"; 459'51.58" LS). Kemudian waktu kejadian dipilih hari hujan lebat yang memiliki akumulasi hujan $>50 \mathrm{~mm} / 24$ jam selama 5 tahun periode musim transisi $2014-2018$ dari stasiun pengamatan Paotere-Makassar. Dari seleksi kejadian hujan lebat musim transisi tersebut didapatkan lima tanggal yakni 24 September 2016, 9 Oktober 2016, 24 Oktober 2016, 22 November 2016, dan 23 September 2017 dengan masing-masing jumlah akumulasi curah hujannya sebesar 52, $127.4,188.7,57.3$, dan $50.9 \mathrm{~mm} / 24 \mathrm{jam}$. 


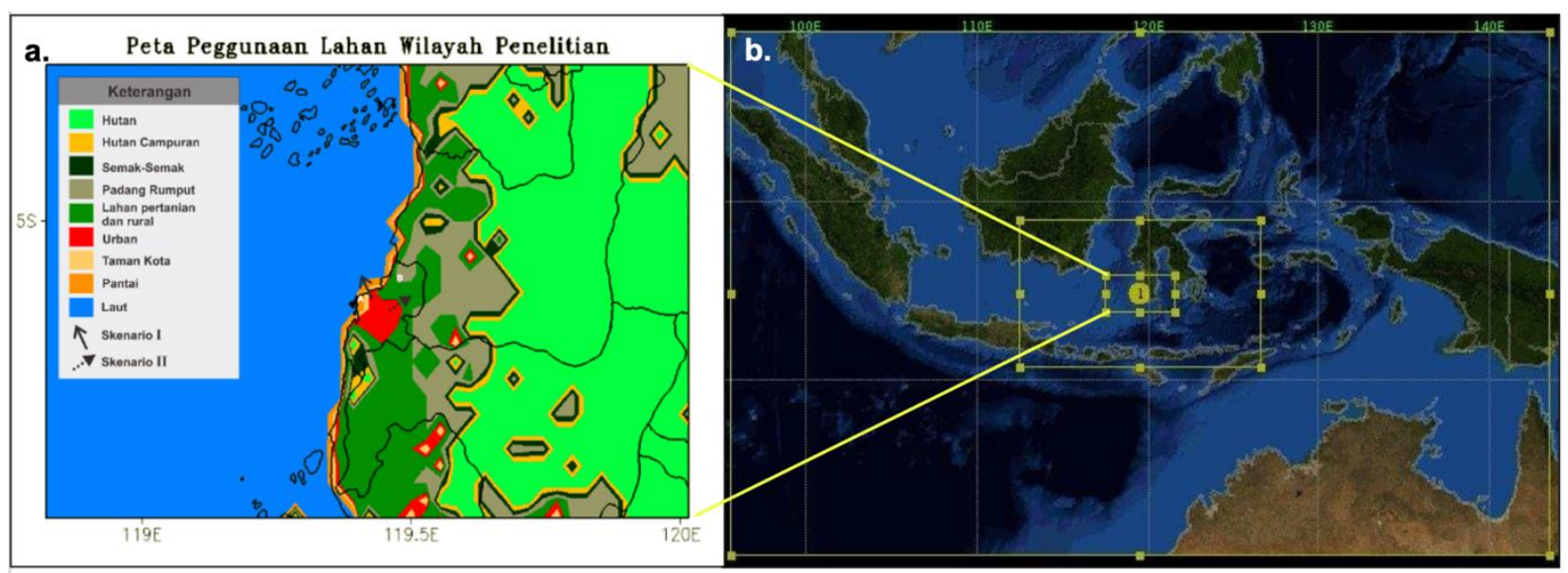

Gambar 1 a). Peta wilayah penelitian pada domain model WRF menggunakan data tutupan lahan Modis sebelum dilakukan modifikasi, dimana huruf A menunjukkan titik Stasiun Maritim Paotere-Makassar dan B adalah titik Stasiun Klimatologi Maros serta b). Tampilan lokasi dan ukuran ketiga domain model WRF

Data yang digunakan pada penelitian ini berupa data observasi, baik manual maupun data dari pengamatan otomatis (AWS) untuk dua stasiun pengamatan (Gambar 1.a). Data observasi berupa data curah hujan per tiga jam dan data suhu permukaan 2-meter per jam. Selain itu penelitian ini juga menggunakan data jumlah penduduk wilayah Kota Makassar pada periode 2007-2017 yang digunakan sebagai perhitungan proyeksi perubahan penggunaan lahan berdasar laju pertumbuhan penduduk sesuai rumusan $P_{t}=P_{o}(1+r) t$; $P_{t}$ adalah jumlah penduduk pada tahun ke- $t, P_{o}$ adalah jumlah penduduk awal tahun, $r$ merupakan laju pertumbuhan penduduk, dan $t$ adalah periode waktu antara tahun awal perhitungan hingga tahun proyeksi (2017-2045).

Dari perhitungan proyeksi laju penduduk, diketahui pada tahun 2045 jumlah penduduk kota Makassar akan meningkat sekitar 37.75\% dari tahun 2017. Kemudian nilai ini dijadikan sebagai acuan untuk pembuatan skenario modifikasi lahan urban sebesar masing-masing 25 dan 50\% untuk dua area yang berbeda, yakni Skenario I modifikasi perluasan wilayah urban untuk daerah reklamasi dan Skenario II modifikasi perluasan wilayah urban di sekitar Universitas Hasanuddin (Tamalanrea) (Gambar 1.a).

Kemudian masing-masing hari kejadian terpilih disimulasikan sesuai skenario dengan menggunakan model non-hidrostatik tiga dimensi Weather Research and Forecasting (WRF) versi 3.9.1 (Powers et al., 2008; Powers et al., 2017). Model menggunakan konfigurasi 3 domain yang masing-masing memiliki resolusi horizontal 27, 9, dan $3 \mathrm{~km}$ (Gambar 1.b) dengan terrain resolution untuk data geografinya masing-masing 10, 5, dan 3 arc-min. Jumlah dimensi grid untuk masing-masing domain adalah 115x81, 103x67, dan 91x55 grid. Model WRF sendiri merupakan model non-hidrostatik yang dibangun dengan menggunakan persamaan primitif (momentum, kontinuitas, gas ideal, termodinamika, dan persamaan konservasi untuk parameter cuaca), perhitungan numerik, metode parameterisasi untuk proses atmosfer yang resolusinya lebih kecil dibandingkan resolusi horizontal model, serta kondisi batas dan model yang pada penelitian menggunakan final analysis (FNL) resolusi spasial $1^{\circ} \times 1^{\circ}( \pm 111 \mathrm{~km})$ yang diperbaharui setiap 6 jam (dapat di unduh dari http://rda.ucar.edu.). Untuk konfigurasi parameterisasi, penelitian ini tidak diawali dengan uji skema, namun konfigurasi mengacu pada penelitian Simamora (2017) dengan modifikasi pada beberapa skema. Adapun rincian skema yang dimaksud adalah penggunaan Single-Moment 3 (WSM3) untuk skema mikrofisika awan, Yonsei University (YSU) untuk skema lapisan batas atmosfer, Grell-Devenyi (GD) untuk 
skema awan cumulus, MM5 similarity untuk skema lapisan permukaan, dan single layer urban canopy model (SLUCM) untuk skema urban. Masing-masing hari kejadian dijalankan oleh model selama 48 jam dengan waktu awal untuk masing-masing tanggal adalah pukul 00.00 UTC/08.00 Local Time (LT), spin-up time 12 jam, dan resolusi temporal keluaran model sebesar 60 menit. Selanjutnya verifikasi model menggunakan metode statistik seperti atribut koefisien korelasi (r), mean absolute error (MAE), dan root mean-square error (RMSE).

\section{HASIL DAN PEMBAHASAN}

\subsection{Evaluasi Kinerja Model WRF}

Sebelum model digunakan untuk mengetahui pengaruh perubahan hujan akibat urbanisasi, model perlu dievaluasi terlebuh dahulu kinerjanya. Hal ini dilakukan untuk memastikan bahwa model mampu menyimulasikan parameter cuaca (suhu dan hujan) yang digunakan sebagai bahan analisis pada penelitian ini.

Tabel 1. Nilai atribut statsitika berupa korelasi (r), MAE, RMSE untuk parameter cuaca yang dievaluasi (suhu, indeks UHI, dan akumulasi hujan selama 24 jam)

\begin{tabular}{|c|c|c|c|c|c|}
\hline \multirow[b]{2}{*}{ Tanggal } & \multirow{2}{*}{$\begin{array}{c}\text { Atribut } \\
\text { Verifikasi }\end{array}$} & \multicolumn{4}{|c|}{ Parameter Cuaca } \\
\hline & & $\begin{array}{c}\text { T Makassar } \\
\left({ }^{\circ} \mathrm{C}\right)\end{array}$ & $\mathrm{T}$ Maros $\left({ }^{\circ} \mathrm{C}\right)$ & $\mathrm{UHI}\left({ }^{\circ} \mathrm{C}\right)$ & $\mathrm{CH}(\mathrm{mm})$ \\
\hline \multirow{3}{*}{ 24-Sep-2016 } & $\mathrm{r}$ & 0.79 & 0.75 & 0.09 & 0.62 \\
\hline & MAE & $1.58^{\circ} \mathrm{C}$ & $1.75^{\circ} \mathrm{C}$ & $1.87^{\circ} \mathrm{C}$ & $1.21 \mathrm{~mm}$ \\
\hline & RMSE & $1.84^{\circ} \mathrm{C}$ & $2.07^{\circ} \mathrm{C}$ & $2.08^{\circ} \mathrm{C}$ & $5.97 \mathrm{~mm}$ \\
\hline \multirow{3}{*}{ 9-Okt-2016 } & $\mathrm{r}$ & 0.58 & 0.09 & 0.26 & 0.23 \\
\hline & MAE & $2.37^{\circ} \mathrm{C}$ & $2.67^{\circ} \mathrm{C}$ & $1.36^{\circ} \mathrm{C}$ & $4.37 \mathrm{~mm}$ \\
\hline & RMSE & $1.83^{\circ} \mathrm{C}$ & $3.22^{\circ} \mathrm{C}$ & $1.78^{\circ} \mathrm{C}$ & $17.53 \mathrm{~mm}$ \\
\hline \multirow{3}{*}{ 24-Okt- 2016} & $\mathrm{r}$ & 0.86 & 0.79 & 0.18 & 0.91 \\
\hline & MAE & $1.11^{\circ} \mathrm{C}$ & $2.30^{\circ} \mathrm{C}$ & $1.76^{\circ} \mathrm{C}$ & $4.25 \mathrm{~mm}$ \\
\hline & RMSE & $1.33^{\circ} \mathrm{C}$ & $2.70^{\circ} \mathrm{C}$ & $2.23^{\circ} \mathrm{C}$ & $18.84 \mathrm{~mm}$ \\
\hline \multirow{3}{*}{ 22-Nov-2016 } & $\mathrm{r}$ & 0.80 & 0.84 & 0.29 & 0.79 \\
\hline & MAE & $1.44^{\circ} \mathrm{C}$ & $2.40^{\circ} \mathrm{C}$ & $1.53^{\circ} \mathrm{C}$ & $1.30 \mathrm{~mm}$ \\
\hline & RMSE & $1.67^{\circ} \mathrm{C}$ & $2.77^{\circ} \mathrm{C}$ & $1.86^{\circ} \mathrm{C}$ & $6.89 \mathrm{~mm}$ \\
\hline \multirow{3}{*}{ 23-Sep-2017 } & $\mathrm{r}$ & 0.60 & 0.67 & 0.34 & 0.25 \\
\hline & MAE & $1.80^{\circ} \mathrm{C}$ & $2.24^{\circ} \mathrm{C}$ & $1.32^{\circ} \mathrm{C}$ & $1.28 \mathrm{~mm}$ \\
\hline & RMSE & $2.11^{\circ} \mathrm{C}$ & $2.93^{\circ} \mathrm{C}$ & $1.76^{\circ} \mathrm{C}$ & $4.77 \mathrm{~mm}$ \\
\hline
\end{tabular}

Tabel 1 menampilkan nilai atribut statistik yang digunakan untuk menilai kinerja model WRF dalam menyimulasikan parameter cuaca berupa suhu, indeks UHI, dan akumulasi curah hujan selama 24 jam untuk masing-masing tanggal kejadian hujan lebat terpilih. Dari kelima hari tersebut diketahui bahwa nilai korelasi untuk suhu udara baik di titik Makassar maupun Maros memiliki rentang $0.09-0.86$, UHI berada pada nilai $0.09-0.34$, dan untuk akumulasi curah hujan pada rentang 0.23 - 0.79. Lalu untuk nilai MAE parameter suhu berada pada rentang nilai $1.11^{\circ}-2.67^{\circ} \mathrm{C}$, untuk UHI antara $1.32^{\circ}$ dan $1.86^{\circ} \mathrm{C}$, dan untuk akumulasi hujan pada rentang $1.21-4.37 \mathrm{~mm}$. Sedang untuk atribut RMSE variabel suhu antara $1.67^{\circ}$ dan $3.22^{\circ} \mathrm{C}$, untuk indeks UHI bervariasi dari $1.76^{\circ}$ hingga $2.08^{\circ} \mathrm{C}$, dan untuk akumulasi curah hujan antara 4.77 dan $18.84 \mathrm{~mm}$. Dari nilai-nilai atribut statistika pada Tabel 1 tersebut diketahui bahwa korelasi untuk tiga parameter tersebut berada pada rentang sangat lemah 
hingga sangat rendah (De Vaus, 2002). Hal ini mengartikan bahwa kemampuan model dalam mengikuti fluktuasi observasi bervariasi. Secara umum untuk parameter suhu udara memiliki korelasi yang lebih baik dan lebih konstan dibandingkan dengan parameter lain. Meskipun terdapat korelasi sangat kuat pada paremeter hujan $(\mathrm{r}=0.91)$, namun nilai tersebut hanya terjadi pada tanggal 24 Oktober 2016, sedangkan untuk tanggal lainnya korelasi bersifat sedang hingga kuat.

Bila Tabel 1 dicermati dengan baik, maka akan diketahui untuk parameter suhu udara dengan korelasi terendah $(\mathrm{r}=0.09)$ dihasilkan oleh model saat menyimulasikan kejadian hujan lebat tanggal 9 Oktober 2016, sedangkan untuk korelasi suhu relatif lebih baik untuk dua titik observasi saat simulasi tanggal 22 November 2016. Hal ini dikarenakan ketika model menyimulasikan suhu udara pada tanggal 8-9 Oktober 2016, model tidak mampu mengikuti penurunan suhu saat terjadi hujan pukul 10.00 - 18.00 LT (Gambar 2.a). Sedangkan untuk simulasi tanggal 21-22 November 2016 model dengan sangat baik mengikuti fluktuasi penurunan suhu saat terjadi hujan lebat pada kurun waktu 12.00 - 18.00 LT (Gambar 2.b). Selain dikarenakan prediktabilitas suhu udara permukaan (2-meter) lebih rendah ketika siang hari dibandingkan malam hari (Zhang et al., 2019), dapat diketahui bahwa suhu juga dipengaruhi oleh kemampuan model dalam menyimulasikan hujan.

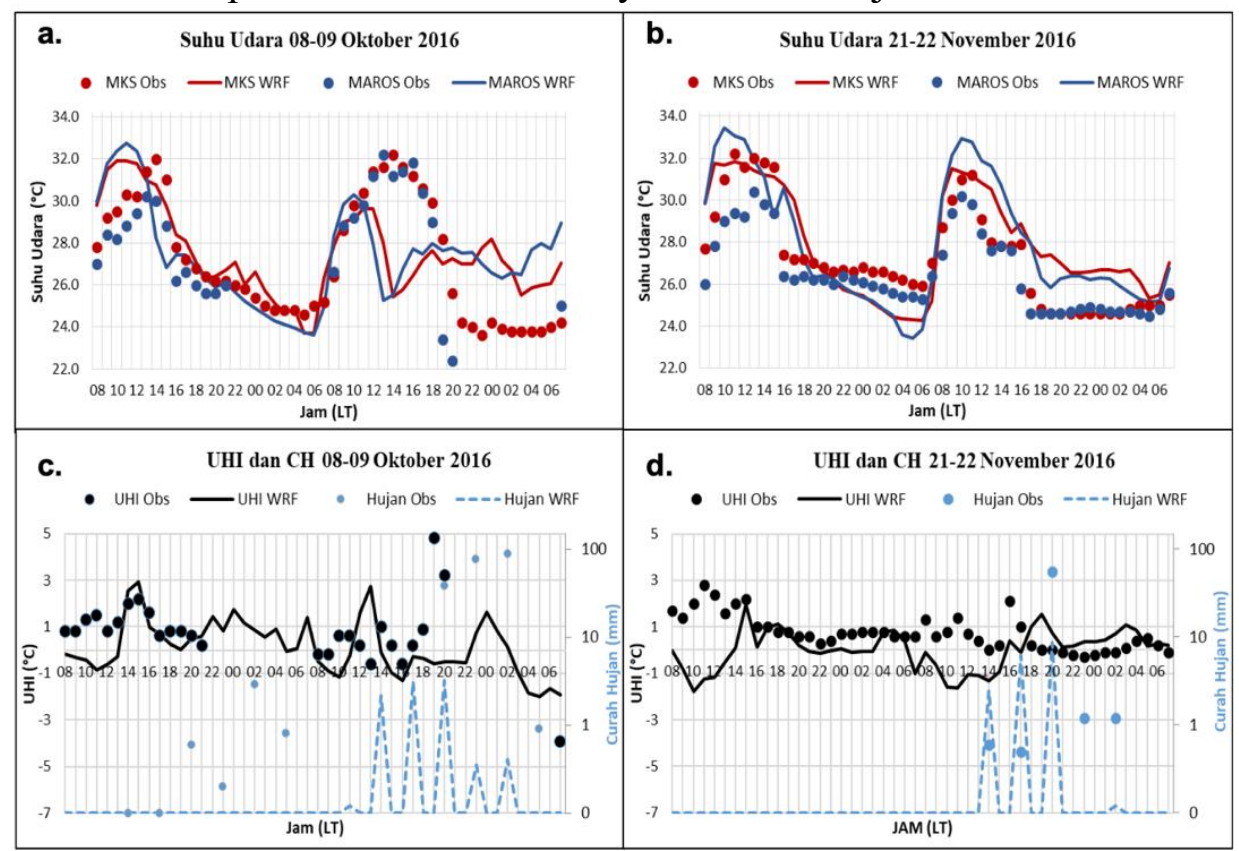

Gambar 2. a-b) Suhu udara ketinggian 2-meter serta c-d). indeks UHI dan curah hujan hujan per jam untuk tanggal 08-09 Oktober 2016 (kiri) dan tanggal 21-22 November 2016 (kanan)

Ketika model mampu menyimulasikan hujan sesuai atau mendekati kejadian hujan observasi, maka nilai parameter suhu udara mengikuti kejadian hujan tersebut. Hal ini dikarenakan hujan mampu menurunkan suhu udara melalui proses saturasi dan pendinginan udara oleh tetes hujan. Masalahnya adalah hujan memiliki prediktabilitas rendah serta sering menghasilkan nilai error tinggi ketika dimodelkan (Lowrey, M.R.K dan Yang Z. L., 2008). Hal ini dikarenakan hujan merupakan parameter yang paling akhir diperhitungkan pada model setelah melewati proses panjang di atmosfer seperti pemanasan, penguapan, dan pembentukan awan. Selain itu pada perhitungan model terdapat hal-hal yang membatasi prediktabilitas hujan seperti penggunaan paremeterisasi kumulus dan mikrofisik awan (Stensrud et al., 2015) serta lama waktu spin-up time (Chu, Q. et. al., 2018). 
Selain dari korelasi, terlihat bahwa MAE dan RMSE untuk suhu dan curah hujan pada simulasi tanggal 8-9 Oktober relatif besar, yakni masing-masing mencapai $2.67^{\circ}$ dan $3.22^{\circ} \mathrm{C}$ pada titik observasi Maros serta mencapai $17.33 \mathrm{~mm}$ untuk curah hujan di titik observasi Paotere-Makassar. Padahal rentang nilai MAE dan RMSE suhu dan curah hujan untuk tanggal lain lebih rendah dari nilai tersebut. Baker, D. et. al. (2009) serta Gilliam dan Pleim (2010) pada penelitian mereka yang juga menggunakan model WRF dengan skema PBL YSU pada musim transisi - kemarau mendapatkan nilai RMSE suhu udara 2-meter berada pada rentang $2.31^{\circ}$ $2.34^{\circ} \mathrm{C}$. Hal ini mengartikan bahwa model WRF yang digunakan pada penelitian ini mampu untuk menyimulasikan suhu udara utamanya di titik observasi Makassar. Sedangkan untuk titik Maros nilai RMSE memang jauh lebih tinggi dibandingkan titik Makassar, yang mengakibatkan tingginya kuantifikasi error dan rendahnya nilai korelasi indeks UHI. Hal ini dapat terjadi akibat pemilihan titik grid pada model yang mungkin terlalu jauh dari titik observasi akibat interpolasi keluaran model atau karena tutupan lahan yang digunakan oleh model masih mengindikasikan titik Maros sebagai lahan hijau (Gambar 1.a) padahal kenyataanya Maros merupakan daerah sub-urban yang terdiri dari 14 kecamatan dan 103 desa/kelurahan (Geografi Maros, 2020).

Selain parameter suhu, dalam menyimulasikan parameter hujan, model WRF cukup mampu mengikuti fluktuasi naik turun curah hujan dengan ditandai korelasi mencapai 0.79 dan MAE sebesar $1.30 \mathrm{~mm}$ pada tanggal 22 November 2016, setidaknya nilai error penelitian ini lebih rendah dibandingkan simulasi yang pernah dilakukan Yucel, I dan Onen, A (2014) yang juga menyimulasikan hujan lebat menggunakan parameterisai kumulus Grell-Devenyi. Selain tanggal 22 November terdapat pula beberapa tanggal yang masih memiliki rentang bias error serupa seperti misal tanggal 22 September 2016 dan 23 September 2017. Perbedaan nilai korelasi dan RMSE antar tanggal tersebut dapat dilihat pada Gambar 2 dimana ketika model tidak mampu menyimulasikan paremeter suhu dan curah hujan, lama waktu spin-up time adalah sumber kesalahan tersebut. Pada tanggal 8-9 Oktober hujan pada observasi terjadi 4 jam setelah model dijalankan, yang dimana periode waktu ini bahkan lebih singkat dari spin-up time terpendek (6 jam). Sehingga model masih belum cukup stabil untuk menyimulasikan hujan yang kemudian berakibat pada mundurnya kejadian hujan hasil simulasi dengan lag-time sekitar 24 jam. Hal ini berbeda dengan tanggal kejadian hujan lebat 22 November 2016 dimana periode waktu running model dapat mengakomodir waktu pemanasan model, sehingga model dengan tepat memprediksi kejadian hujan meskipun terdapat lag-time satu jam (Gambar 2.d). Selain masalah kurang lamanya spin-up time saat simulasi, penggunaan skema Grell-Devenyi mungkin perlu ditinjau ulang untuk kasus hujan lebat khusunya di daerah Makassar. Hal ini dikarenakan pada penelitian Igri, P. M. et al., (2018) yang juga menyimulasikan hujan lebat, skema Grell-Devenyi menghasilkan error yang besar akibat ketidakmampuannya dalam merepresentasikan proses konveksi secara benar. Namun sayangnya paremeter konveksi dan uji skema cumulus di luar batas masalah penelitian ini.

Dari evaluasi kinerja model WRF dalam mensimulasikan lima kejadian hujan lebat untuk paremeter suhu udara dan curah hujan, setidaknya diketahui bahwa tiga dari lima kasus dapat disimulasikan dengan baik oleh model, dimana hujan terjadi sesuai dengan observasi, sedangkan dua hari yang lain hujan pada observasi terjadi pada saat proses pemanasan model sedang berlangsung (gambar tidak ditampilkan). Sehingga terkait skenario modifikasi terhadap luasan wilayah urban, hanya kejadian hujan tanggal 24 September 2016, 22 November 2016, dan 23 September 2017 yang digunakan untuk analisis skenario modifikasi wilayah urban. 


\subsection{Analisis skenario modifikasi wilayah urban}

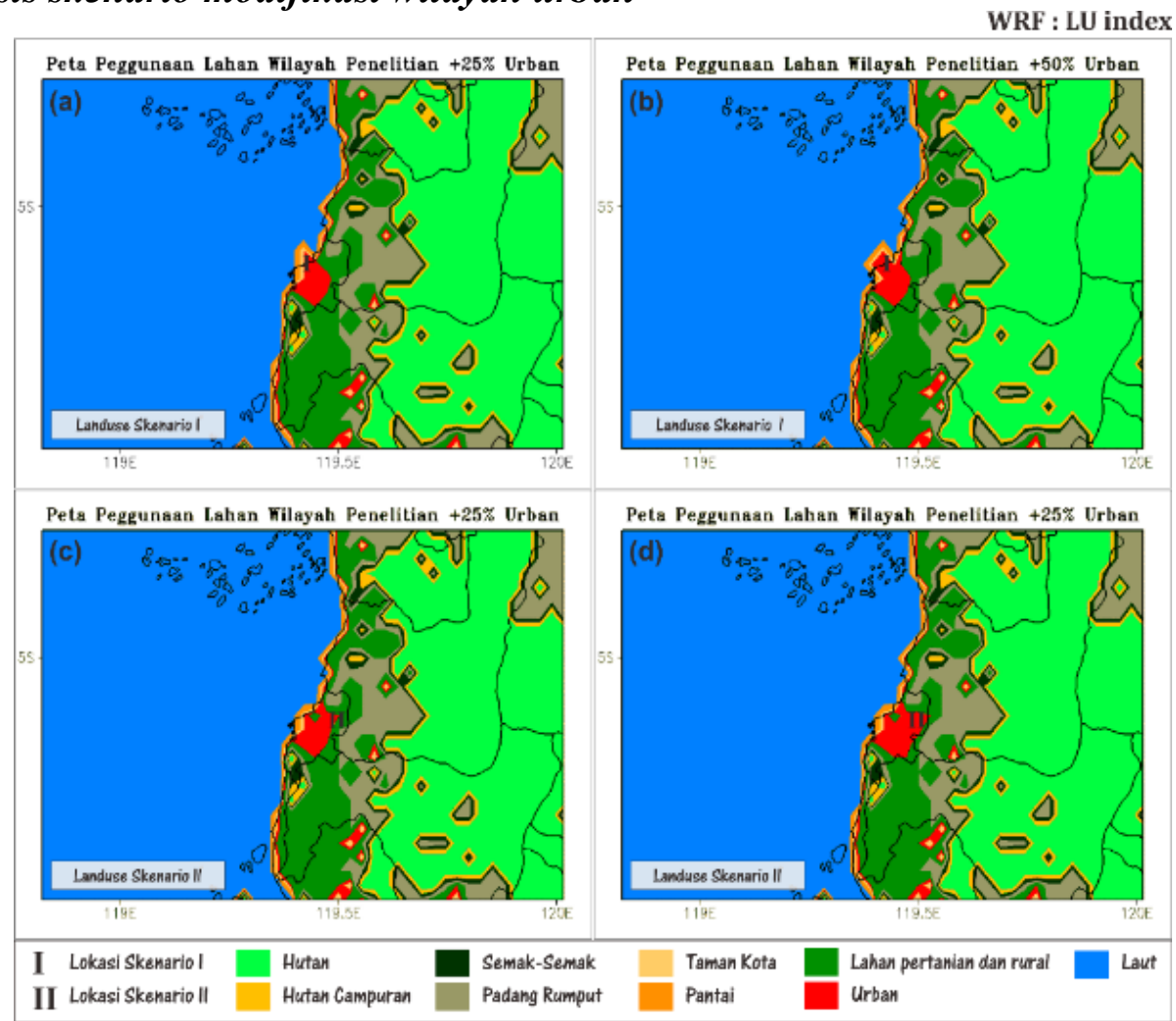

Gambar 3. Peta wilayah penelitian WRF Modis a). setelah modifikasi sesuai dengan skenario I dengan pertambahan wilayah urban $+25 \%$ dan b). $+50 \%$, serta c). setelah modifikasi sesuai dengan skenario II dengan pertambahan wilayah urban $+25 \%$ dan d). $+50 \%$

Dari hasil running model yang menerapkan skenario modifikasi perluasan wilayah perkotaan (Gambar 3) didapatkan nilai parameter cuaca berupa nilai indeks UHI maksimum dan akumulasi hujan 24 jam pada masing-masing tanggal yang layak untuk dianalisis sesuai pembahasan pada sub-bab 3.1. Tabel 2 menunjukkan dua dari tiga kejadian hasil perluasan wilayah meningkatkan nilai indeks UHI maksimum antara $0.1^{\circ}$ hingga $1.5^{\circ} \mathrm{C}$. Pada tanggal 23 September 2017, dua skenario modifikasi untuk dua skema perluasan wilayah berhasil meningkatkan nilai indeks UHI maksimum, sedangkan untuk tanggal 24 September 2016 hanya skenario I dengan perluasan $25 \%$ yang malah menghasilkan indeks UHI maksimum lebih rendah dari kejadian non-modifikasi. Hal ini dimungkinkan karena perluasan wilayah ke arah perairan terhalang oleh garis pantai sehingga perluasan wilayah sebesar $25 \%$ tidak semaksimal ketika dilakukan ke arah daratan (perkotaan) (Gambar 3).

Untuk akumulasi hujan 24 jam peningkatan berkisar antara $1.0-3.0 \mathrm{~mm}$ dari skema nonmodifikasi. Terlihat bahwa hanya tanggal 24 September 2016 yang mengalami peningkatan hujan akibat adanya perluasan wilayah. Sedangkan untuk tanggal lain peningkatan akumulasi hujan tidak konsisten. Bahkan, untuk tanggal 23 September 2017 ketika nilai UHI maksimum meningkat untuk semua skenario, akumulasi hujan mengalami penurunan. Hal ini menunjukkan bahwa urbanisasi dapat meningkatkan nilai UHI namun pemanasan udara pada daerah perkotaan belum tentu berpengaruh terhadap kejadian hujan. Meskipun Trenberth (2011) dalam penelitiannya menyimpulkan bahwa kejadian hujan ekstrim berkaitan dengan tingginya saturasi kandungan uap air pada atmosfer yang hangat, namun pada penelitian ini hangatnya suhu udara tidak diikuti dengan peningkatan jumlah akumulasi hujan. Hal ini dikarenakan hujan 
merupakan produk akhir yang fisisnya tidak dapat dilihat hanya dari satu variabel. Selain itu hujan memiliki proses interaksi yang tidak linear pada setiap variabel pembentuknya. Proses fisis seperti peningkatan kelembaban, pelemahan sirkulasi udara, perpindahan zona konvergensi, serta interaksi non-linear lainnya pada masing-masing parameter yang semi-linear perlu dipertimbangkan terkait analisis perubahan hujan (Chadwick, R. dan Good, P., 2013).

Tabel 2. Akumulasi UHI dan CH hasil modifikasi skenario pada tiga kejadian hujan lebat di wilayah Makassar

\begin{tabular}{clcccccc}
\hline \multirow{2}{*}{$\begin{array}{c}\text { Tanggal } \\
\text { kejadian }\end{array}$} & \multicolumn{1}{c}{ Parameter cuaca } & \multicolumn{3}{c}{ Skenario I } & \multicolumn{3}{c}{ Sekenario II } \\
\cline { 2 - 8 } & $\begin{array}{c}\text { Non- } \\
\text { Modif }\end{array}$ & $\begin{array}{c}\text { Urban } \\
+25 \%\end{array}$ & $\begin{array}{c}\text { Urban } \\
+50 \%\end{array}$ & $\begin{array}{c}\text { Non- } \\
\text { Modif }\end{array}$ & $\begin{array}{c}\text { Urban } \\
+25 \%\end{array}$ & $\begin{array}{c}\text { Urban } \\
+50 \%\end{array}$ \\
\hline \multirow{2}{*}{ 24-Sep-2016 } & UHI max. $\left({ }^{\circ} \mathrm{C}\right)$ & 1.1 & 0.9 & 1.3 & 0.9 & 1.0 & 1.1 \\
\cline { 2 - 8 } & $\begin{array}{l}\text { Akumulasi Hujan } \\
(\mathrm{mm})\end{array}$ & 3.7 & 4.7 & 6.7 & 4.1 & 3.8 & 5.9 \\
\hline \multirow{2}{*}{$22-$-Nov-2016 } & UHI max. $\left({ }^{\circ} \mathrm{C}\right)$ & 1.6 & 0.8 & 1.5 & 1.1 & 0.6 & 0.9 \\
\cline { 2 - 8 } & $\begin{array}{l}\text { Akumulasi Hujan } \\
(\mathrm{mm})\end{array}$ & 11.0 & 9.3 & 12.4 & 14.5 & 11.8 & 10.4 \\
\hline \multirow{2}{*}{ 23-Sep-2017 } & \begin{tabular}{l} 
UHI max. $\left({ }^{\circ} \mathrm{C}\right)$ \\
\cline { 2 - 8 } \\
\cline { 2 - 8 }
\end{tabular} & 2.0 & 3.9 & 3.5 & 2.6 & 3.4 & 3.9 \\
\hline Ketmulasi Hujan & 1.7 & 0.1 & 1.1 & 4.9 & 4.1 & 4.6 \\
\hline
\end{tabular}

Keterangan:

Meningkat dari Non-Modif

Menurun dari Non-Modif

Sebagai kejadian yang memiliki hasil sesuai dengan hipotesis, dimana urbanisasi dapat meningkatkan UHI dan akumulasi hujan di wilayah perkotaan, maka kejadian hujan lebat 24 September 2016 perlu dianalisis lebih lanjut terkait sebaran hujan secara spasial dan temporalnya. Pada Gambar 4 terlihat bahwa dengan perluasan 50\% untuk wilayah kota, rataan suhu meningkat antara $0.05^{\circ}$ sampai $0.30^{\circ} \mathrm{C}$ dibandingkan sebelum modifikasi saat kejadian hujan lebat 24 September 2016. Namun pemusatan peningkatan suhu udara antara skenario I dan II sedikit berbeda. Pada skenario I, peningkatan suhu terlihat lebih tinggi dan lebih luas dibandingkan skenario II. Selain itu pada skenario I, pusat daerah yang lebih hangat berada pada wilayah reklamasi, sedangkan untuk skenario II, pusat daerah hangat sedikit bergeser ke arah timur laut mendekati Maros. Akibatnya, kenaikan indeks UHI maksimum pada hari tersebut tidak terlalu signifikan bila dibandingkan dengan kejadian hujan lebat 23 September 2016 yang dapat mencapai $1.9^{\circ} \mathrm{C}$ (Tabel 2). Pada skenario I yang dimana suhu udara lebih hangat di wilayah reklamasi, secara spasial juga terlihat akumulasi hujan 24 jam meningkat $50 \%(2.5 \mathrm{~mm})$, sedangkan pada skenario II akumulasi hujan cenderung normal bahkan mengalamai penurunan dibandingkan skenario non-modifikasi. Hal ini dikarenakan gradien suhu permukaan di wilayah pantai dapat memengaruhi pola sirkulasi lokal seperti angin laut yang kemudian juga berdampak pada perpindahan uap air dan terjidinya konvergensi udara di wilayah kota tepi pantai (Kusaka, H. et al., 2013). 


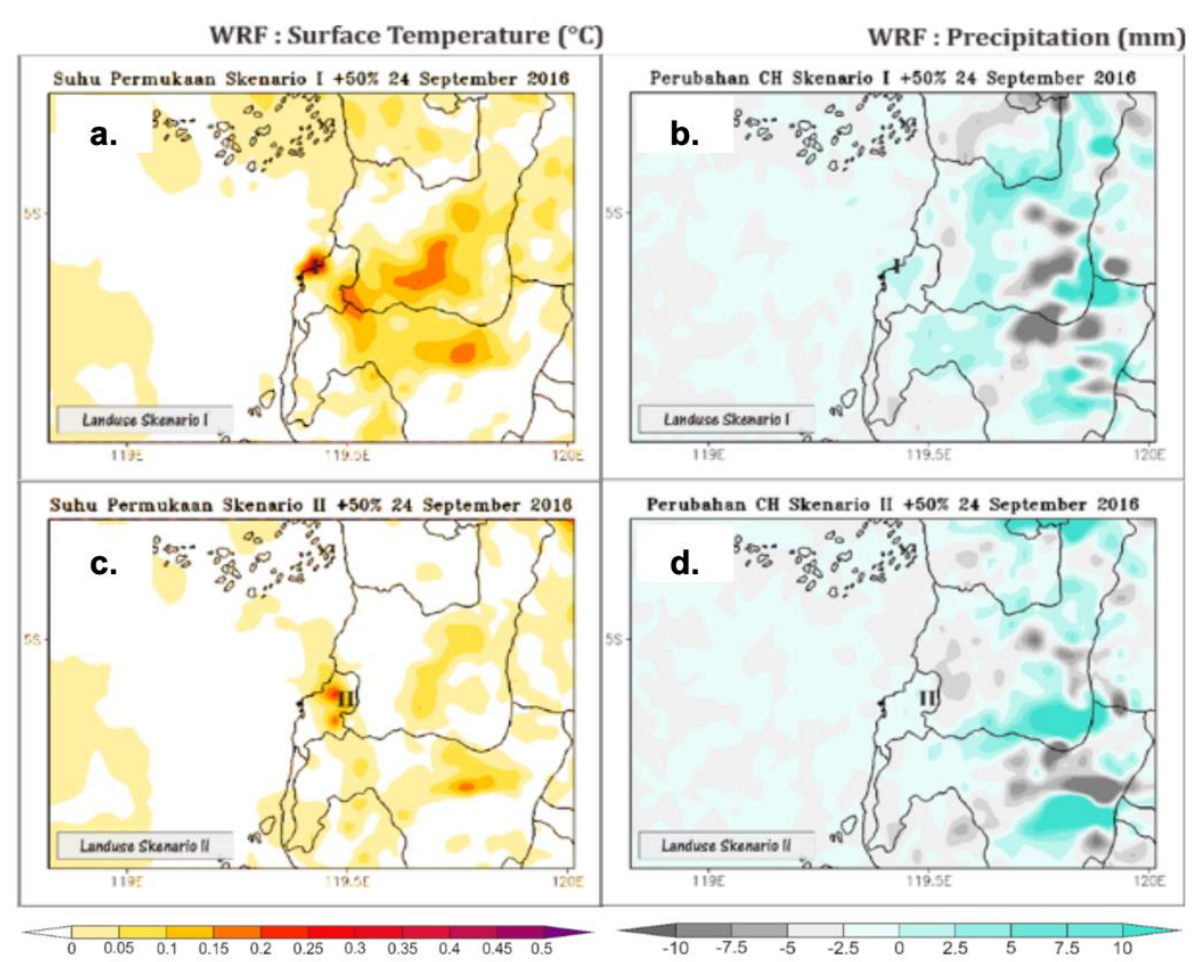

Gambar 4. Hasil perluasan area perkotaan sebesar 50\% untuk peningkatan parameter ratarata suhu permukaan $\left({ }^{\circ} \mathrm{C}\right)$ (kiri) serta akumulasi hujan spasial (mm/24jam) (kanan) pada skenario I (a,c) dan skenario II (b,d) dari skenario non-modifikasinya tanggal 24 September 2016

Secara temporal terlihat bahwa pada kejadian hujan 24 September 2016 indeks UHI cenderung naik perlahan disekitar nilai $1^{\circ} \mathrm{C}$ pada pukul $18.00 \mathrm{LT}$ dan mencapai puncaknya pada pukul 22.00 LT untuk skenario I dan pukul 20.00 LT untuk skenario II (Gambar 5). Selain kejadian hujan 24 September 2016, dua tanggal lain (22-Nov-2016 dan 23-Sep-2017) juga memiliki UHI puncak pada jam serupa. Ini menandakan adanya penambahan wilayah perkotaan menyebabkan terjadianya norcturnal UHI di wilayah Kota Makassar, meskipun nilai ini lebih rendah dari hasil penelitian Karlický, J., et al. (2018) yang juga menggunakan model WRF dengan parametrisasi SLUCM. Sedangkan untuk puncak hujan pada dua skenario terjadi pada pukul 21.00 LT, terlepas dari puncak UHI pada skenario I terjadi lebih lambat dari jam tersebut. Ini menandakan bahwa pemanasan udara di Kota Makassar tidak berkontribusi secara langsung terhadap kejadian hujan lebat 24 September 2016, meskipun Lin, et al. (2011) menemukan bahwa sistem hujan cenderung terjadi ketika malam dengan intensitas lebat akibat adanya wilayah perkotaan. Hal ini dikarenakan analisis yang dilakukan hanya pada suhu dan indeks UHI, padahal proses fisis dan dinamis pembentukan hujan termasuk jenis awan penghasil hujan perlu dilakukan agar keseluruhan proses interaksi dapat diketahui. Namun sayangnya analisis tersebut diluar batasan masalah penelitian ini. 


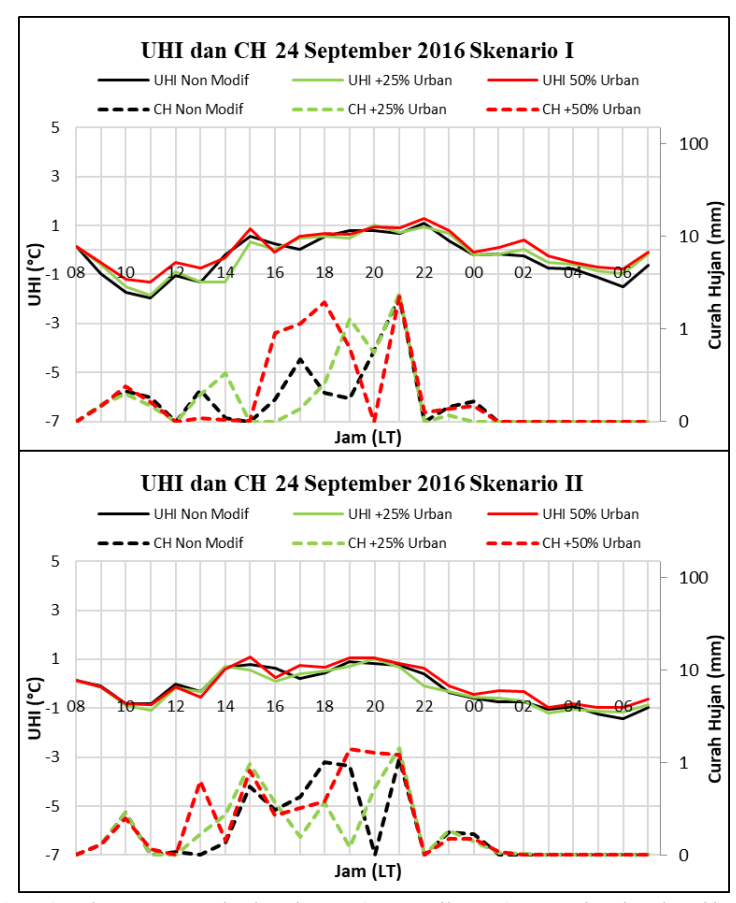

Gambar 5. Nilai UHI $\left({ }^{\circ} \mathrm{C}\right)$ dan curah hujan (mm/jam) pada kejadian tanggal 24 September 2016 untuk skenario I (atas) dan skenario II (bawah)

\section{KESIMPULAN}

Dari evaluasi pada model yang dilakukan, tiga dari lima hari kejadian hujan lebat selama musim transisi 2014 - 2018 dapat disimulasikan dengan baik oleh model. Nilai RMSE, MAE dan korelasi untuk parameter suhu udara 2-meter serta akumulasi hujan 48 jam sebanding dengan literatur. Kejadian hujan tanggal 24 September 2016 dan 23 September 2017 yang disimulasikan menggunakan dua sekenario modifikasi berhasil meningkatkan nilai UHI maksimum sebesar $0.1^{\circ}-1.5^{\circ} \mathrm{C}$, namun kenaikan ini tidak diikuti dengan peningkatan akumulasi hujan, yang menandakan adanya proses non-linear dalam pembentukan hujan. Selain itu dari simulasi kejadian hujan tanggal 24 September 2016 diketahui peningkatan hujan lebih intens $(50 \%)$ dan lebih luas sebarannya ketika perluasan wilayah dilakukan di area reklamasi, sedangkan untuk wilayah perkotaan (inland area) hujan cenderung normal bahkan mengalami penurunan.

\section{SARAN}

Meskipun nilai RMSE, MAE ddan korelasi antara observasi dan hasil model sebanding dengan literatur, namun nilai ini masih cukup besar. Sehingga untuk pengoptimalan kinerja model pada penelitian selanjutnya dapat dilakukan evaluasi atau uji parameterisasi terlebih dahulu pada model. Sebab kinerja Model WRF bervariasi terhadap lokasi, konfigurasi, serta kejadian yang disimulasikan. Selain itu pada penelitian ini analisis hanya didasarkan pada suhu udara, indeks UHI, dan paremeter hujan. Sehingga untuk mengetahui keterkaitan proses nonlinear kejadian hujan perlu dilakukan analisis terkait jenis awan dan kejadian hujan, uap air, sirkulasi udara, konveksi dan konvergensi udara.

\section{DAFTAR PUSTAKA}

Baker, D., et al., 2009. Sensitivity Testing of WRF Physics Parameterizations for Meteorological Modeling and Protocol in Support of Regional SIP Air Quality. Modeling in the OTR. Ozone Transport Commission Modeling Committee. 
BAPPENAS. (2019). Visi Indonesia 2045. Menteri Perencanaan Pembangunan Nasional, Jakarta.

BPS Kota Makassar. (2017). Kota Makassar Dalam Angka 2017. BPS-Statistics Indonesia, Makassar

Chadwick, R. and Good, P. (2013). Understanding nonlinear tropical precipitation responses to CO2 forcing. Geophys. Res. Lett., 40, 4911-4915. https://doi.org/10.1002/grl.50932, 2013

Chu, Q., Xu, Z., Chen, Y., \& Han, D. (2018). Evaluation of the ability of the Weather Research and Forecasting model to reproduce a sub-daily extreme rainfall event in Beijing, China using different domain configurations and spin-up times. Hydrology and Earth System Sciences. https://doi.org/10.5194/hess-22-3391-2018

Delarizka, A., Sasmito, B., dan Hani'ah. (2016). Analisis Fenomena Pulau Bahang (Urban Heat Island) di Kota Semarang Berdasarkan Hubungan Antara Perubahan Tutupan Lahan Dengan Suhu Permukaan Menggunakan Citra Multi Temporal Landsat. Jurnal Geodesi Undip. Semarang.

De Vaus, D. A. (2002). Survey in Social Research, fifth edition. Allen and Unwin: New South Wales.

Geografi Maros. (2020, Agustus 31). Retrieved from https://maroskab.go.id/geografi/

Gilliam, R. C., \& Pleim, J. E. (2010). Performance assessment of new land surface and planetary boundary layer physics in the WRF-ARW. Journal of Applied Meteorology and Climatology. https://doi.org/10.1175/2009JAMC2126.1

Han, J.-Y., Baik, J.-J., \& Lee, H. (2014). Urban impacts on precipitation. Asia-Pacific Journal of Atmospheric Sciences, 50(1), 17-30. https://doi.org/10.1007/s13143-014-0016-7

Igri, P. M., Tanessong, R. S., Vondou, D. A., Panda, J., Garba, A., Mkankam, F. K., \& Kamga, A. (2018). Assessing the performance of WRF model in predicting high-impact weather conditions over Central and Western Africa: an ensemble-based approach. Natural Hazards, 93(3), 1565-1587. https://doi.org/10.1007/s11069-018-3368-y

Ihsan, H., Sanusi, W., Matematika, J., Matematika, F., Alam, P., \& Negeri, U. (2019). Peramalan Pola Curah Hujan Di Kota Makassar Menggunakan Model Rantai Markov. Journal of Mathematics, Computations, and Statistics, 2(1), 19-30.

Kusaka, H., Nawata, K., Suzuki-Parker, A., Takane, Y., \& Furuhashi, N. (2014). Mechanism of precipitation increase with urbanization in Tokyo as revealed by ensemble climate simulations. Journal of Applied Meteorology and Climatology, 53(4), 824-839. https://doi.org/10.1175/JAMC-D-13-065.1

Lin, C.-Y., Chen, W.-C., Chang, P.-L., \& Sheng, Y.-F. (2011). Impact of the Urban Heat Island Effect on Precipitation over a Complex Geographic Environment in Northern Taiwan. Journal of Applied Meteorology and Climatology, 50(2), 339-353. https://doi.org/10.1175/2010JAMC2504.1

Lowrey, M. R. K., \& Yang, Z. L. (2008). Assessing the capability of a regional-scale weather model to simulate extreme precipitation patterns and flooding in central Texas. Weather and Forecasting. https://doi.org/10.1175/2008WAF2006082.1

Niyogi, D., Lei, M., Kishtawal, C., Schmid, P., \& Shepherd, M. (2017). Urbanization impacts 
on the summer heavy rainfall climatology over the eastern United States. Earth Interactions. https://doi.org/10.1175/EI-D-15-0045.1

Paida. (2011). Deteksi Perubahan Pola Curah Hujan Kota Makassar. Skripsi. Universitas Hasanuddin Makassar.

Powers, G., Huang, X.-y., Klemp, B., Skamarock, C., Dudhia, J., Gill, O., Wang, W. (2008). A description of the advanced research wrf version 3.

Powers, J. G., Klemp, J. B., Skamarock, W. C., Davis, C. A., Dudhia, J., Gill, D. O., .Duda, M. G. (2017, 09). The Weather Research and Forecasting Model: Overview, System Efforts, and Future Directions. Bulletin of the American Meteorological Society, 98(8), 1717-1737. doi: 10.1175/BAMS-D-15-00308.1

Prasasti, I., Sari, N. M., dan Febrianti, N. (2015). Analisis Perubahan Sebaran Pulau Panas Perkotaan (Urban Heat Island ) di Wilayah DKI Jakarta dan Hubungannya dengan Perubahan Lahan, Kondisi Vegetasi dan Perkembangan Kawasan Terbangun Menggunakan Data Penginderaan Jauh. Pusat Pemanfaatan Penginderaan Jauh LAPAN. Jakarta.

Simamora, J. R. (2017). Uji Sensitivitas Skema Parameterisasi Model WRF-ARW Untuk Analisis Hujan Sangat Lebat Di Wilayah Makassar. Skripsi. Sekolah Tinggi Meteorologi Klimatologi dan Geofisika, Tangerang Selatan.

Stensrud, D., Coniglio, M., Knopfmeier, K. H., \& Clark, A. (2015). Numerical models: Model physics paramterization. Encyclopedia of Atmospheric Science (Second Edition), 2, $167-180$.

Syamsudin, F., dan Sopia, L. (2017). Dampak Pemanasan Pulau Perkotaan (Urban Heat Island) pada Peningkatan Tren Curah Hujan Ekstrem dan Aerosol di Megapolitan Jakarta Sejak 1986. Jurnal Teknologi Lingkungan-BPPT. Jakarta.

Trenberth KE. (2011). Changes in precipitation with climate change. Clim. Res. 47(4): 123138, doi: $10.3354 / \mathrm{cr} 00953$.

UN-HABITAT. (2013). Kajian Kerentanan Perubahan Iklim Kota Makassar. Makassar

$\mathrm{Yu}$, M., \& Liu, Y. (2015). The possible impact of urbanization on a heavy rainfall event in Beijing. Journal of Geophysical Research. https://doi.org/10.1002/2015JD023336

Yucel, I., \& Onen, A. (2014). Evaluating a mesoscale atmosphere model and a satellite-based algorithm in estimating extreme rainfall events in northwestern Turkey. Natural Hazards and Earth System Sciences. https://doi.org/10.5194/nhess-14-611-2014

Zhang, T., Li, Y., Duan, H., Liu, Y., Zeng, D., Zhao, C., Gong, C., Zhou, G., Song, L., \& Yan, P. (2019). Development and evaluation of a WRF-based mesoscale numerical weather prediction system in Northwestern China. Atmosphere, 10(6). https://doi.org/10.3390/atmos10060344 